\title{
KÖZÉPISKOLAI DIÁKOK MUNKÁHOZ ÉS TOVÁBBTANULÁSHOZ FÜZŐDŐ VISZONYA
}

\author{
KOCSIS ZSÓFIA \\ Debreceni Egyetem
}

\begin{abstract}
Kutatásunkban olyan Hajdú-Bihar megyei középiskolákat kerestünk fel, ahol magas a hátrányos helyzetü tanulók aránya. A 9. és 11. évfolyam tanulóinak a továbbtanulási terveit és munkatapasztalatait vizsgáltuk, online és papíralapú kérdőívek segítségével. A diákok céljai között kismértékben jelent meg a továbbtanulási szándék, a munkaerőpiacon való elhelyezkedés fontosabb volt számukra. A diákok egy része már rendszeresen vállal munkát a középiskolai évei alatt, azonban nincs szignifikáns összefüggés a munkavállalás és a szülők foglalkoztatottsága között. Továbbá megfigyelhető volt, hogy a munkavállaló diákokban talán a munkatapasztalataik révén jobban körvonalazódtak jövőbeli céljaik és továbbtanulásra vonatkozó terveik.
\end{abstract}

Kulcsszavakः középiskolai munkavállalás, továbbtanulási szándék, diákmunka

In our research, we examined some high schools in the Hajdú-Bihar county where the proportion of disadvantaged students is extremely high. We researched the students' plans for further education and work experience in the 9th and 11th classes, we used online and paper based questionnaires. We collected the students' goals, their position in the labor market was more important to them than to continue their studies. Some of the students are already working regularly during their high school years, but there is no significant correlation between the work and the parents' employment. Furthermore, it could be observed that the students who work are more decided of their future goals and further education.

Keywords: secondary school work, intent to study, student work

\section{Fiatalok a munka világában}

$\mathrm{N}$ apjainkban a középiskolás korosztály is egyre aktívabban vesz részt a munka világában, aminek számos oka lehet (anyagi kényszer, szakmai tapasztalat megszerzése, a szülőktől való függetlenedés vágya, szabadidős tevékenységek

Levelező szerző: Kocsis Zsófia, Debreceni Egyetem, 4032 Debrecen, Egyetem tér 1.

E-mail: zsofikocsis6@gmail.com 
finanszírozása). A munkavégzéssel kapcsolatos döntés nemcsak a jelenlegi és a későbbi munkavállalást, hanem a tanulmányaikhoz való viszonyt is befolyásolhatja. Szeretnénk bemutatni, hogy milyen munkatapasztalatokkal rendelkeznek napjainkban a középiskolások, és milyen terveik vannak a jövőre nézve. A fiatalok életében már nincs egy meghatározott, előre megjósolható időpont, amikor bekapcsolódnak a munka világába (Bocsi 2013). A 16. életév betöltésével, illetve ha nappali képzésű rendszerben folytatják a tanulmányaikat, már munkaviszonyt létesíthetnek, (Bókay 2009). Nemcsak hazai viszonylatban, de nemzetközi szinten is megnőtt a részmunkaidős foglalkoztatás mértéke a középiskolások körében az utóbbi évtizedekben (Singh 1998). A Központi Statisztikai Hivatal 2010. IV. negyedévi adatai szerint a nappali tagozatos tanulmányok melletti munkavállalás nem túl gyakori Magyarországon, a KSH ifjúsági moduljának az adatai alapján kimutatható, hogy a 15-24 évesek körében a foglalkoztatási arány 18,7\%, ezen belül a nappali tagozatos oktatásban résztvevőké 3,7\%.

Számos hazai és külföldi kutató foglalkozott a fiatalok munkavállalási szokásaival, valamint a munkavégzés és a családi háttér, az iskolatípus, a településtípus, az életkor és a nem kapcsolatával (Warren-LePore-Mare 2000; Csoba 2013; Pusztai 2013; Szöcs 2014; Kocsis 2017). A Magyar Ifjúság 2012-es empirikus adatai alapján elmondható, hogy a munkavégzés gyakorisága, elterjedtsége kapcsolatban áll az életkorral és az iskola típusával (Gazsó 2012). Szöcs (2014) eredményei szerint az állami és önkormányzati középiskolák diákjai nagyobb arányban végeznek diákmunkát egyetemi hallgatóként is. Warren és munkatársai szerint azok a középiskolások, akik alacsonyabb státusú családból származnak, intenzívebben vállalnak fizetett munkát (Warren-LePore-Mare 2000). Néhány kutatásban (Kocsis 2017) viszont azt tapasztalták, hogy a szülők iskolai végzettsége nincs hatással a későbbi munkavállalásra. Csoba (2013) szerint fokozatos átmenet figyelhető meg a tanulás és a munka között. Az általa megkérdezett fiatalok 73,7\%-a már a középiskolai tanulmányai alatt is vállalt munkát. A háttérváltozók mellett a munkavállalás hatását is kutatják, legfóképpen a lemorzsolódásra való hatást. Már a nyolcvanas években kutatásokat végeztek azzal kapcsolatban, hogy a munka megjelenésével csökken a tanulásra, kikapcsolódásra fordított idő, valamint az intenzív munkavállalás a lemorzsolódás kockázatát is feltételezte (D’Amico 1984). Vickers és munkatársai kutatása szerint a heti 5 óránál intenzívebb, rendszeres munkavégzés a középiskolások körében lemorzsolódást eredményezhet (Vickers-Lamb-Hinkley 2003). A negatív hatások mellett a munka jövőbeli megtérülését is vizsgálták. A középiskolában végzett munka fejlődési előnyökkel jár, egy évtizeddel később is pozitív hatást gyakorolhat a munkaerőpiaci részvételre, a foglalkoztatási státuszra, a juttatásokra és a jövedelemre, valamint valószínübb, hogy a közeljövőben teljes munkaidőben foglalkoztatják őket, és nem lesznek munkanélküliek a későbbiekben (Mortimer 1994; Rubm 1997; Carr-Wright-Brody 1996; Vickers-LambHinkley 2003).

A végzős középiskolások továbbtanulási tervei között egyértelműen szerepel a munkanélküliség elkerülése, a biztosnak vélt munkaerőpiaci kilátás és a karrierépítés (JancsákPolgár 2010). Kispálné és Vincze (2009a) végzős középiskolások terveit összegezte, ahol célként szerepelt: a munkaadók elvárásain felüli tapasztalatszerzés, a nyári és szorgalmi időszakban történő munkavállalás. Az egyetemi tanulmányok befejezése után sokaknál felmerült a külföldi munkavégzés, valamint a mesterképzésben való részvétel. Megfigyelhető volt, hogy minél magasabb a szülők iskolai végzettsége, annál nagyobb mértékben nőtt a saját elképzelés és a szülői tanács szerepe (Kispálné-Vincze 2009b). 
Látható, hogy a továbbtanulás mellett már megjelennek a munkavállalásra vonatkozó törekvések. A fiatalok egyre jobban tisztában vannak azzal, hogy a megfelelő intézmény kiválasztása, valamint a korai munkatapasztalatok szerzése hasznos lehet a jövőbeli megtérülés szempontjából.

\section{A kutatásról}

A Wáli István Református Cigány Szakkollégium kezdeményezésére a Debreceni Egyetem Felsőoktatási Kutató és Fejlesztő Központja (CHERD) 2018 tavaszán komplex kutatást végzett a hátrányos helyzetü tanulók továbbtanulását támogató tényezőkről. A 2016. évi 10. évfolyamos telephelyi OKM adatbázisa alapján azokat a Hajdú-Bihar megyei középiskolákat kerestük meg, ahol az átlagot meghaladó volt a roma/cigány származású, sajátos nevelési igényü, tanulási nehézségekkel küzdő, veszélyeztetett, évfolyamismétlő, valamint rendszeres gyermekvédelmi támogatásban részesülő tanulók aránya (Pusztai et al. 2018). Az iskolákban a 9. és a 11. évfolyam osztályait kérdeztük ki tanórai keretek között online és papíralapú kérdőív segítségével.

A jelenlegi vizsgálatban a középiskolások munkához való viszonyára, továbbtanulási szándékukra és jövőbeli terveikre fókuszáltunk. Felmértük, hogy a munka hogyan van jelen az életükben, s ebben a hátrányos helyzetű régióban mennyire érvényesül a munkaerőpiac vonzó hatása. Vajon a munkaerőpiacon való részvétel sokkal vonzóbb és reálisabb cél, mint az egyetemi hallgatóvá válás?

\section{„Mi leszek, ha nagy leszek?”}

Úgy véltük, hogy fontos megvizsgálni, milyen célokkal rendelkeznek a tanulók, hogyan viszonyulnak a munkához és a továbbtanuláshoz. A céljaik között a felvételi vagy a munkavállalás szerepel-e?

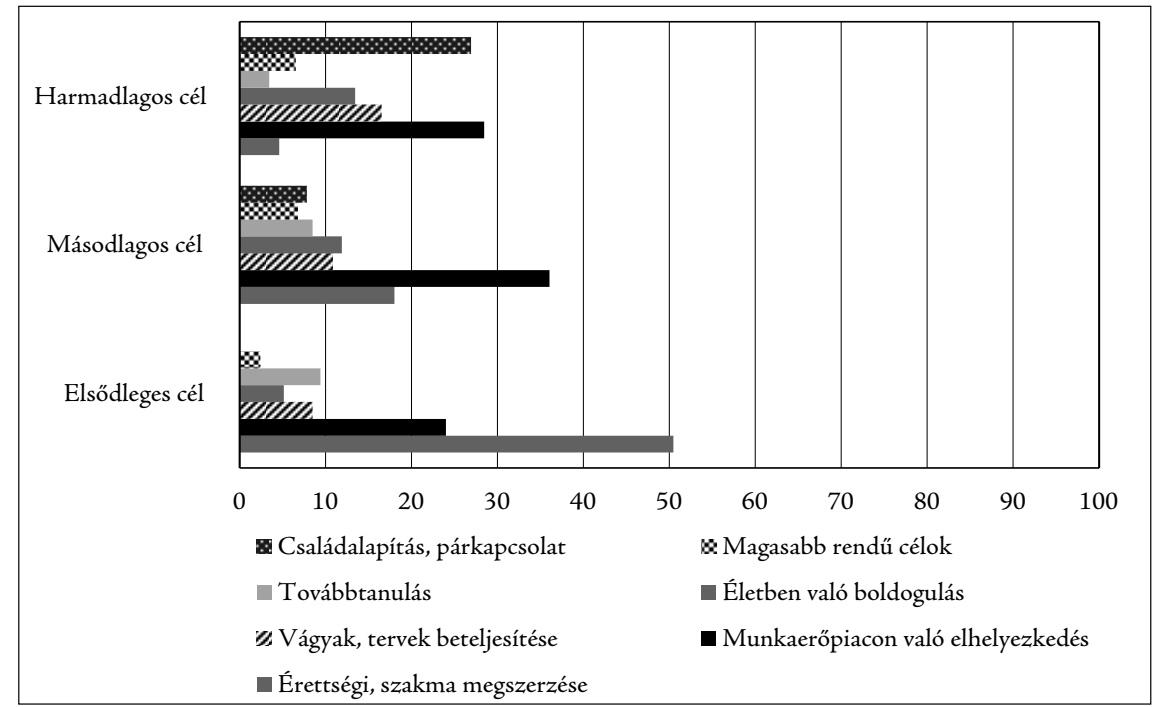

1. ábra: Hosszú távú célok $(N=329)$. Forrás: saját szerkesztés 
A válaszadók egyötöde nem nevezett meg egyetlen célt sem. A diákok elsődleges céljai között szerepelt a végzettség megszerzése, majd a munkaerőpiacon való elhelyezkedés, 24\%-uk konkrét szakmákat, munkahelyeket nevezett meg. A válaszadók alig 10\%-a jelölte meg a továbbtanulást mint elsődleges célt. A második legfontosabb cél megnevezésekor szintén kiemelkedő helyen volt a munkaerőpiacon való elhelyezkedés $(36,1 \%)$, a továbbtanulásra irányuló célok hasonló arányban jelentek meg. A harmadik cél megnevezésénél a munkaerőpiacon való elhelyezkedés a diákok 28,5\%-ának továbbra is fontos. Összességében azt láthatjuk, hogy az elhelyezkedés nagyobb arányban jelenik meg a célok megnevezésekor, míg a továbbtanulás kisebb arányban ugyan, de szerepel a diákok távlati céljai között. A továbbtanulás mint lehetőség a családi és környezeti minta hiánya, illetve ezen opció szubjektív valószínütlensége miatt nem szerepelhet magas arányban a tervek között.

A munkavállalás a családi mintákkal is összefüggésbe hozható. A munkára szocializálás funkciója nemcsak hosszú távon jelent nehézséget, hanem a tanulás munkaként való értelmezésében is. Továbbá a gyermeknevelés egyik lehetséges formája is lehet. Ugyanis néhány szülő számára fontos, hogy a gyerekek fiatalon munkatapasztalatokat szerezzenek, legyen az diákmunka vagy családon belüli, ismerősök által szerzett munka. A válaszadók 70\%-a nyilatkozott úgy, hogy édesapjának/nevelőapjának a lekérdezés pillanatában volt bejelentett állása, míg az édesanyák/nevelőanyák esetében 57,3\%-nak. A diákok 12\%-ának sem az édesapja, sem az édesanyja nem dolgozott. A munkavállaláshoz a válaszadók 37,2\%-a a családjuktól kapta a legtöbb segítséget, illetve 15,3\%-uk a rokonoktól. Alig $8 \%$-uk kapott segítséget a tanáraiktól. A legkevesebb arányban jelölték meg a munkaügyi és a pályaválasztási tanácsadótól való segítséget. Érdekes, hogy a kisvárosban és falun élő diákok tartják legmagasabb arányban fontosnak a tanárok és a tanácsadók véleményét. A diákok csaknem 10\%-a senkire nem számíthat munkakeresés szempontjából.

\section{Középiskolai munkavállalás}

A megkérdezett diákok többsége sohasem dolgozott, sem szünidőben, sem iskolai időszakban. A válaszadók 18,1\%-a mindig vállalt munkát a szünidőben, míg 6,5\%-uk az iskolai időszakban is. A nemek szerinti megoszlás alapján nem találtunk szignifikáns különbséget. A fiúk 22,8\%-a vállalt munkát a szünidőkben, míg az iskolai időszakban 9\%-uk dolgozik rendszeresen. A lányok 15,6\%-a dolgozik nyaranta, szünetekben, és 5\%uk a tanév során is vállal munkát.

A látott minták, a munkához való viszony az iskolai siker, eredményesség előkészítője lehet, ezért a korábbi kutatásokhoz (Pusztai 2009; Bocsi 2015) hasonlóan megvizsgáltuk, milyen szempontokat tartanak fontosnak a munkahely kiválasztása során. A munkaértékeket egy ötfokozatú skálán értékelték. A megkérdezettek nagyjából azonos módon fontosnak tartották a felsorolt munkaértékeket, azonban a legfontosabbnak a biztos munkahelyet $(73,9 \%)$ és a jó fizetést $(73,7 \%)$ tartják. A régió hátrányos helyzetéből adódóan nem meglepő, hogy a munkahelyválasztás során ezek az értékek dominálnak. Ezt követően a diákok fontosnak tartották még a jó munkakörülményeket (69\%), az elörejutási lehetőségeket (65,4\%) és a kevés stressz meglétét (64,2\%). Nemek tekintetében nincs számottevő és lényeges különbség a munkaértékek rangsorában. A fiúknál a negyedik helyen az előrejutás és szakmai fejlődés áll, míg a lányoknál a kevés stressz és az előreju- 


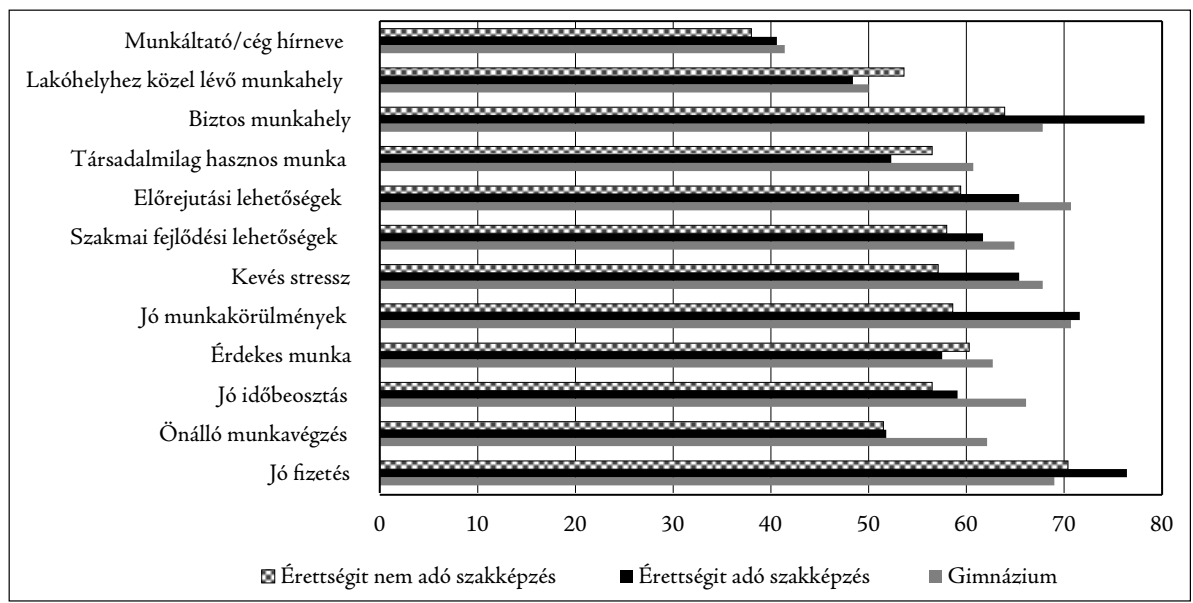

2. ábra: Az iskolatípus és a munkaértékek összefüggése $(N=318)$. Forrás: saját szerkesztés

tási lehetőségek. Mindkét nemnél elhanyagolható jelentőségű a munkáltató cég neve és a lakóhelyhez való közelség.

Szignifikáns összefüggést találtunk az iskola típusa és az önálló munkavégzés ( $p=$ $0,002)$, a jó munkakörülmények $(p=0,004)$, az elörejutási lehetőségek $(p=0,000)$ és a biztos munkahely $(p=0,000)$ esetében. Az érettségit nem adó szakképzésben tanulók számára a legfontosabb a jó fizetés (70,4\%), a biztos munkahely $(63,9 \%)$ és az érdekes munka (60,3\%). Az érettségit adó szakképzésben részt vevő diákok 78,2\%-a szerint is a munkahely biztonsága, míg 76,4\%-uk véleménye alapján a jó fizetés a legfontosabb. A jó munkakörülmények a megkérdezettek 71,6\%-nak lényeges. A gimnazistáknak azonban egyaránt a jó munkakörülmények és az előrejutási lehetőségek a legfontosabbak (70,7\%), ezt követi a megfelelő fizetés (69\%). Összességében azonban elmondható, hogy akár a teljes mintán, akár iskolatípusonként vizsgáljuk a munkaértékeket, a legjobban a külső motivációs tényezők dominálnak, míg a belső motiváción alapuló munkaértékek jelentősen háttérbe szorulnak. Ennek okai a diákok társadalmi hátterében gyökereznek.

\section{Továbbtanulási tervek}

Annak ellenére, hogy a céljaik felsorolásakor a továbbtanulási szándék alacsony rátájával találkoztunk, a diákok 34,3\%-a válaszolta, hogy szeretne továbbtanulni, 27\%-nak határozott elképzelése van arról, hogy milyen szakra szeretne menni, vagy milyen szakmát szeretne tanulni. A megkérdezettek közül legnagyobb arányban a gimnazisták (66,2\%) szeretnének továbbtanulni. A válaszadók 17,4\%-a tartotta valószínünek, hogy folytatja tanulmányait, míg 4,4\%-uk úgy vélte, hogy egyáltalán nem fog továbbtanulni a középiskola után. A legnagyobb arányban (27,6\%) az OKJ-s képzéseket, majd a felsőfokú szakképzéseket jelölték meg. A megkérdezettek 18,8\%-ának volt elképzelése arról, hogy a tanulmányait egyetemen, nappali tagozaton folytatja tovább. Az OKJ-képzést nagyobb arányban választották a dolgozó diákok, valamint főiskolai képzésben is a munkavállaló tanulók közül szeretnének a legnagyobb arányban részt venni. A munkavállaló diákokban talán a munkatapasztalataik révén jobban körvonalazódtak a céljaik és a továbbtanulásra vonatkozó terveik. 


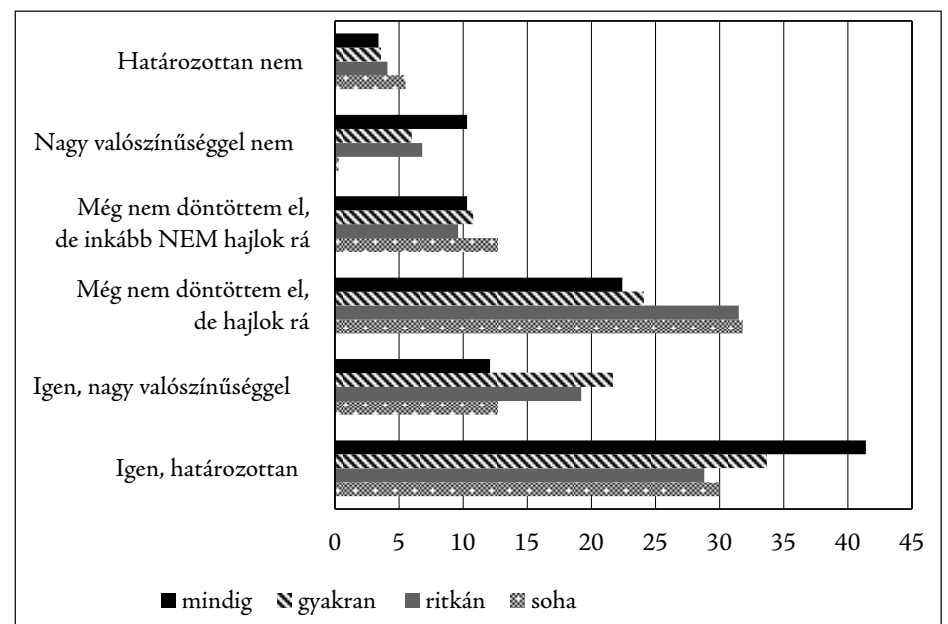

3. ábra: A szünidei munkavállalás gyakorisága és a továbbtanulási szándék összefüggései $(N=324)$. Forrás: saját szerkesztés

A legnagyobb arányban (41,4\%) azok szeretnének továbbtanulni, akik a szünidejükben mindig dolgoztak. Öket követik azok, akik gyakran dolgoztak a szünetekben. Magyarázatként szolgálhat a munka nevelő szerepe, feltételezhetjük, hogy azoknak a tanulóknak, akik dolgoztak, sokkal határozottabb és kiforrottabb elképzelésük van a jövőjüket illetően. Láthatjuk azt is, hogy akik ritkán vagy soha nem dolgoztak, azok a legbizonytalanabbak abban, hogy szeretnének-e továbbtanulni vagy sem, viszont 30\%-uk egyértelműen tovább szeretne tanulni. A rendszeresen dolgozó diákok közül kerültek ki azok is magasabb arányban, akik úgy gondolják, hogy nem fognak továbbtanulni a középiskola után. Ha a tanév közben végzett munkavállalást hasonlítjuk össze a továbbtanulási szándékkal, hasonló eredményeket kapunk. Akik iskolai időben rendszeresen dolgoztak,

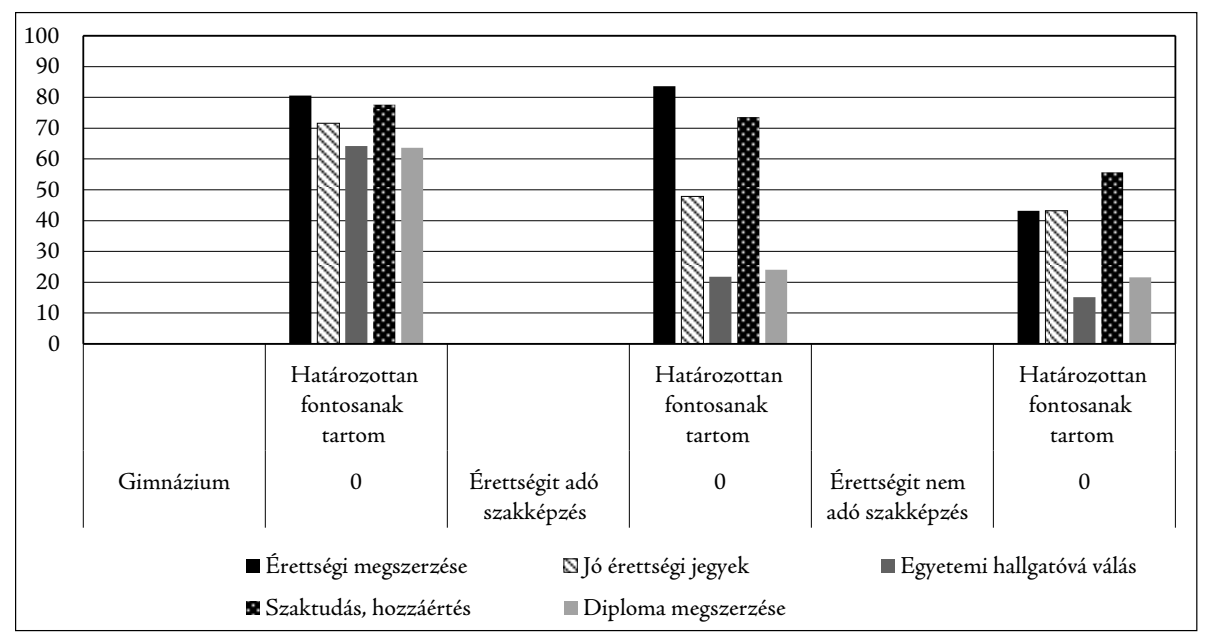

4. ábra: Az életben való érvényesüléshez szükséges tényezők megítélése iskolánként $(N=346)$.

Forrás: saját szerkesztés 
közülük választották legnagyobb arányban az OKJ-képzést, valamint a munkavállaló tanulók közül szeretnének a legnagyobb arányban föiskolai képzésben is részt venni .

$\mathrm{A} z$ életben való érvényesülés szempontjából több mint 70\%-uk szerint a szaktudás nagyon fontos az életben, amely akár a munkaerőpiacon való elhelyezkedésüket nagymértékben javítaná. A megkérdezettek több mint a negyede gondolja úgy, hogy a diploma megszerzése nem fontos ahhoz, hogy boldoguljanak az életben. Iskolatípusonként szignifikáns különbséget találtuk a fent említett tényezők fontosságának megítélésében (sig.: 0,000).

A gimnazisták körében az érettségi megszerzése és a szaktudás, hozzáértés a legfontosabb, hasonlóan vélekednek az érettségit adó szakképzésben résztvevő tanulók is. $\mathrm{Az}$ érettségit nem adó képzésben tanulók számára egyértelmüen a szaktudás megléte a leglényegesebb tényező. A továbbtanulás inkább a gimnazistáknak fontos, a diákok körében a szaktudás, a munkaerő-piaci jelenlét fontosabb, mint a továbbtanulás.

\section{Összegzés}

A Hajdú-Bihar megyei középiskolák hátrányos helyzetű 9. és 11. évfolyamos diákjainak munkához füződő viszonyát és továbbtanulási szándékát igyekeztünk feltárni. Kutatásunkból kiderült, hogy már a diákok ötöde szünidőben is dolgozott, és 6,5\%-uk a tanév közben is rendszeresen vállalt munkát. A jövőbeli célok esetében nagymértékben megjelent a munkaerőpiacon való elhelyezkedés vágya, konkrét szakmák és munkahelyek megnevezése, azonban a továbbtanulási szándék alacsony arányával találkoztunk. Azok, akik szeretnének továbbtanulni, főként az OKJ-képzéseket és felsőfokú szakképzéseket preferálták, azonban a munkavállaló diákok egy része gondolkodik azon, hogy a felsőoktatásban is részt vegyen. Továbbá megfigyelhető volt, hogy a munkavállaló diákokban talán a munkatapasztalataik révén jobban körvonalazódtak a jövőbeli céljaik és a továbbtanulásra vonatkozó terveik. Továbbá érdemes lenne részletesebben megvizsgálni más iskolákat is, kiegészítve a középiskolai munkavállalás pozitív, illetve negatív hatásával a továbbtanulási szándékra s a jövőbeli tervekre vonatkozólag.

\section{IRODALOM}

Bocsi V. (2013) Munkaértékek a felsőoktatásban. In: Darvai T. (ed.) Felsőoktatás és munkaeröpiac - eszményektöl a kompetenciák felé. SETUP. Szeged, Belvedere Meridionale. pp. 67-87.

Bocsi V. (2015) A felsőoktatás értékmetszetei. Budapest, Új Mandátum.

Bóкау M. (2009) A diákok nyári munkavállalásának alapvető szabályai. Adóvilág, Vol. XXIII. No. 7. pp. 2-4.

Carr, R. V, Wright, J. D. \& Brody, C. J. (1996) Effects of High School Work Experience a Decade Later: Evidence from the National Longitudinal Survey. Sociology of Education, Vol. 69. No. 1. pp. 66-81.

Creed, P. A. \& Patton, W. (2003) Differences in Career Attitude and Career Knowledge for High School Students with and without Paid Work Experience. International Journal for Educational and Vocational Guidance, Vol. 3. No. 1. pp. 21-33. 
Csова J. (2013) Munka és tanulás. A felsőfokú képzésben részt vevő hallgatók munkatapasztalata. Esély, Vol 24. No. 4. pp. 30-50.

D’Amico, R. (1984) Does Employment during High School Impair Academic Progress? Sociology of Education, Vol. 57. No. 3. pp. 152-164.

Gazsó T. (2012) Munkaerőpiaci helyzetkép. In: Székely L. (ed.) Magyar Ifjúság 2012. Tanulmánykötet. Budapest, Magyar Közlöny Lap- és Könyvkiadó. pp. 127-152.

JANCSÁ K Cs. \& Polgár Zs. (2010) Középiskolások továbbtanulási motivációi és jövőorientációi. Új Ifjúsági Szemle, Vol. VIII. No. 3. pp. 27-35.

Kispálné Horvá M. \& Vincze Sz. (2009a) Végzős középiskolások felsőoktatással kapcsolatos tájékozottsága és tervei. Új Pedagógiai Szemle, Vol. 60. Nos 3-4. pp. 39-49.

Kispálné Horvá M. \& Vincze Sz. (2009b) Végzös középiskolások továbbtanulással kapcsolatos motivációi, döntései és az azokat befolyásoló tényezök. https://www.researchgate. net/publication/319103046_Vegzos_kozepiskolasok_tovabbtanulassal_kapcsolatos_ motivacioi_dontesei_es_az_azokat_befolyasolo_tenyezok [Letöltve: 2018.07.27.]

Kocsıs Zs. (2017) Debreceni és nagyváradi egyetemisták munkavállalási szokásainak összehasonlítása. In: Tóth P., Hanczvik kel A. \& Duchon J. (eds) Tanulóközpontú oktatás, módszertani megújulás a szakképzésben és a felsőoktatásban. VII. Trefort Âgoston Tanárképzési Konferencia Tanulmánykötet. pp. 169-187.

Mortimer, J. T. (1994) Work Experience in Adolescence. Journal of Vocational Education Research, Vol. 19. No. 1.pp. 39-70.

Pusztai G. (2009) A társadalmi tőke és az iskola. Budapest, Új Mandátum.

Pusztai G. (2013) A felsőoktatás munkára felkészítő szerepe a hallgatók értelmezésében. In: Kun A. \& Polónyi I. (eds) Az Észak-Alföldi régió helyzete. Képzés és munkaeröpiac. Budapest, Új Mandátum Kiadó. pp. 9-29.

Pusztai G., Bocsi V., Bacskai K., Ceglédi T., Csokai A., Kocsis Zs. \& Szűcs T. (2018) A jelen és jövö határán. Hátrányos helyzetü középiskolások és hallgatók eredményessége. Debrecen, CHERD Hungary, Debreceni Egyetem.

Ruнм, C. J. (1997) Is High School Employment Consumption or Investment? Journal of Labor Economics, Vol. 15. No. 4. pp. 735-776.

Singh, K. (1998) Part-Time Employment in High School and Its Effect on Academic Achievement. The Journal of Educational Research, Vol. 91. No. 3. pp. 131-139.

Szőcs A. (2014) Dolgozva tanulni, tanulva dolgozni - társadalmi tőke hatások a partiumi hallgatók körében. In: Ceglédi T., Gál A. \& NAGY Z. (eds) Régió és oktatás IX. Debrecen, CHERD Hungary. pp. 229-242.

Vickers, M., Lamb, S., \& Hinkley, J. (2003) Student Workers in High School and Beyond: The Effects of Part-Time Employment on Participation in Education. Training and Work. https://files.eric.ed.gov/fulltext/ED475343.pdf [Letöltve: 2018. 07. 27.]

Warren, J. R., LePore, P. C. \& Mare, R. D. (2000) Employment during High School: Consequences for Students' Grades in Academic Courses. American Educational Research Journal. http://journals.sagepub.com/doi/10.3102/00028312037004943 [Letöltve: 2018. 07. 27.]

A cikk a Creative Commons Attribution 4.0 International License (https://creativecommons.org/licenses/ by/4.0/) feltételei szerint publikált Open Access közlemény, melynek szellemében a cikk bármilyen médiumban szabadon felhasználható, megosztható és újraközölhető, feltéve, hogy az eredeti szerző és a közlés helye, illetve a CC License linkje és az esetlegesen végrehajtott módosítások feltüntetésre kerülnek. (SID_1) 